\title{
Conformation of Phylogenetic Relationship of Penaeidae Shrimp Based on Morphometric and Molecular Investigations ${ }^{1}$
}

\author{
P. Rajakumaran ${ }^{a}$, B. Vaseeharan ${ }^{a}$, R. Jayakumar ${ }^{b}$, and R. Chidambara ${ }^{c}$ \\ ${ }^{a}$ Crustacean Molecular Biology and Genomics Lab, Department of Animal Health and Management, \\ Alagappa University, India \\ ${ }^{b}$ Mandapam Regional Centre, Central Marine Fisheries Research Institute (CMFRI), Mandapam Camp, \\ Tamil Nadu, 623520 India \\ ${ }^{c} R \& D$ Department, National Prawn Co., Al-Laith, Jeddah, 21961 Saudi Arabia \\ *e-mail: vaseeharanb@gmail.com \\ Received May 8, 2013
}

\begin{abstract}
Understanding of accurate phylogenetic relationship among Penaeidae shrimp is important for academic and fisheries industry. The Morphometric and Randomly Amplified Polymorphic DNA (RAPD) analysis was used to make the phylogenetic relationsip among 13 Penaeidae shrimp. For morphometric analysis forty variables and total lengths of shrimp were measured for each species, and removed the effect of size variation. The size normalized values obtained was subjected to UPGMA (Unweighted Pair-Group Method with Arithmetic Mean) cluster analysis. For RAPD analysis, the four primers showed reliable differentiation between species, and used correlation coefficient between the DNA banding patterns of 13 Penaeidae species to construct UPGMA dendrogram. Phylogenetic relationship from morphometric and molecular analysis for Penaeidae species found to be congruent. We concluded that as the results from morphometry investigations concur with molecular one, phylogenetic relationship obtained for the studied Penaeidae are considered to be reliable.
\end{abstract}

Keywords: Penaeidae, shrimp, morphometry, RAPD, phylogeny

DOI: $10.3103 / \mathrm{S} 0095452714060103$

\section{INTRODUCTION}

Penaeidae shrimps worldwide are classified into 26 genera and 225 species, of which 13 genera are found along the Indian coasts. It is a diverse and worldwide distributed family of shrimps, particularly in the Indo-West Pacific region and contributes to $50 \%$ of crustacean fisheries in the world [1]. In India Penaeidae shrimps constitute a highly valuable fishery along the East and West coasts. The estimated Indian landings of Penaeidae shrimps in 2010 was 2, 17, $900 \mathrm{mt}$, contributing $51 \%$ of total crustacean landings [2].

Generally, the Penaeidae shrimp differs from non Penaeidae by pattern of arranging of pleurae regularly, third pereopods chelated and abdominal segment do not has sharp bend but non-Penaeidae prawns the pleurae of the second abdominal segment are overlapping those of first and third segments; third pereopods not chelated and abdominal segment has sharp bend in the non-Penaeidae prawns. Moreover in Penaeidae shrimp, the distinguished identical characters are the rostral structure, rostral teeth, antenna colouration and body colour with strips. In majority of the Penaeidae shrimp, rostral teeth are important charac-

\footnotetext{
${ }^{1}$ The article is published in the original.
}

ters to distinguish the different species and also within the groups. In Penaeus sensu lato group, the rostral teeth are present both in the upper and lower portions of the rostrum, and but in other case, the rostral teeth are present only in the dorsal side of the rostrum. Moreover depending on the nature of carapace the Penaeus sensu lato can be divided as Melicertus (grooved) and non-Melicertus (non-grooved). Carapace with longitudinal suture, lacking transverse suture and fourth and fifth pairs of pereopods with elongate dactyl subdivided into articles in Xiphopenaeus, carapace with longitudinal, transverse sutures, and fourth and fifth pair of pereopods with dactyl neither elongate nor subdivided into articles in Trachypenaeus.

Penaeidae into three tribes according to the characters of gill formula (presence or absence of epipod on the third maxilliped and pleurobranch on the fifth pereopod), spination of the antennular peduncle (presence or absence of a spine on the ventromedian margin of proximal segment) and the telson (tip simple or trifid), namely the Peneini (Penaeus, Heteropenaeus, Funchalia, Pelagopenaeus), the Parapeneini (Parapenaus, Artemesia, Penaeopsis, Metapenaeopsis), and the Trachypeneini (Metapenaeus, Macropetasma, Trachypenaeopsis, Atypopenaeus, Protrachypene, 
Xiphopenaeus, Parapenaeopis, Trachypenaeus) [3]. Penaeidae shrimp, on the basis of complex morphological similarity matrix into five groups; 1 -Penaeus; 2-Penaeopsis; 3-Atpopenaeus, Trachypenaeopsis, Metapenaeus; 4-Parapenaeus, Parapenaeopsis, Trachypenaeus; 5-Metapenaeopis [4].

The extraordinary morphological diversity among these species poses substantial challenge to their phylogenetic study. Limited fossil records and incomplete palaeogeographic evidences are of little significant in phylogenetic studies of Penaeidae [5, 6]. The system of morphometric measurements called the truss network system have been widely used for population and taxonomic studies [7-11]. The conservation of body skeleton and definite body ratio facilitated using trussnet work system as a taxonomical tool to differentiate physically similar species and compared to traditional morphological method such tool can be used as clear, accurate and precise descriptor [12]. The morphometric measurements have been used to describe the taxonomical relationship between Melicertus kerathurus, Metapenaeus dobsoni and Penaeus semisulcatus [13]. Apart from morphological characters, the shape and size evolutionary relationship species of Penaeidae species is limited. Hence in the present study the truss network system was used to analyses the phylogenetic relationship by morphometry with concerning shape and size.

The molecular analysis using PCR-based markers has been of great significance on studying the phylogeny and taxonomy. Random amplification of polymorphic DNA (RAPD) is random amplification of anonymous loci by PCR. The method is simple, rapid and cheap, has high polymorphism, requires only a small amount of DNA and allows creation of genomic markers from species of which little information is known about the target sequences to be amplified. RAPD markers are produced by PCR using short oligonucleotide primers of random sequences. Different RAPD patterns arise when genomic regions vary according to the presence/absence of complementary primer annealing sites. RAPDs have gained considerable attention particularly in population genetics, species and subspecies identification, phylogenetics, linkage group identification, chromosome and genome mapping, analysis of interspecific gene flow and hybrid speciation, and analysis of mixed genome samples breeding analysis and as a potential source for single-locus genetic fingerprints [14]. Randomly amplified polymorphic DNA (RAPD) data showed higher levels of polymorphism than allozymes [15]. Allozyme has limitations for highly divergent group $[15,16]$.

The robust taxonomy is both the morphological and molecular data agreement [17]. Molecular data are a complementary approach to morphology, especially in discriminating cryptic or sibling species [18, 19] and for constructing phylogenetic relationships
[15]. Raymunida - squat lobsters (formerly in genus Munida), distinguished by small morphological differences, which matched clear differences in mitochondrial nucleotide sequences [20]. Data are available from studies of mitochondrial marker like cytochrome oxidase subunit I, and 12S and 16S rRNA (ribosomal RNA). However, analyses by non nuclear marker alone or combined, still have not provided a reliable taxonomy for Penaeidae shrimps. Nuclear DNA marker only provides high resolution to resolve the evolutionary relationship of the shrimp [6, 21]. Only mitochondrial DNA marker observation is available on Penaeidae phylogeny [22, 23], but lot of studies on phylogeny of super family Penaeoidea are there, where only the least explanation about the Penaeidae shrimp as one of the family along with four other family Aristaeidae, Solenoceridae, Benthesicymidae, Sicyonidae [24-26]. Moreover the other studies are Penaeus sensu lato [27, 28] and Penaeus sensu strict [29-31]. Previously several morphometric and genetic analysis were conducted for species variation and systematic studies for various fishes [32-35]. Currently, there is no report available on phylogenetic relationship of Penaeidae species analysed employing both morphometry and Nuclear DNA molecular marker. In the present study, we have used both the techniques, with diverse shrimp, to conform the phylogenetic relationship of Penaeidae shrimp species.

\section{MATERIALS AND METHODS}

Collection of samples. Six species from Penaeus genus (1) Fenneropenaeus indicus (H. Milne Edwards, 1837), (2) Fenneropenaeus merguiensis (De Man, 1888), (3) Melicertus latisulcatus (Kishinouye, 1896), (4) Penaeus monodon (Fabricius, 1798), (5) Penaeus semisulcatus (De Haan, 1844), (6) Marsupenaeus japonicas (Bate, 1888); three species from Parapenaeopsis genus (1) Parapenaeopsis stylifera (H. Milne Edwards, 1837), (2) Parapenaeopsis hardwickii (Miers, 1878), (3) Parapenaeopsis uncta (Alcock, 1905); two species from Metapenaeus genus (1) Metapenaeus monoceros (Fabricius, 1798), (2) Metapenaeus dobsoni (Miers, 1878), Metapenaeus affinis (H. Milne Edwards, 1837) and one species from Penaeopsis genus Penaeopsis jerryi (Perez Farfante, 1979), totally thirteen species were collected from the East coast of India. All species were identified according to published literature [36-38].

Multivariate cluster analysis of morphometric data. After identification of species, from each species 5 male sample only taken and female omitted due to size variation. The measurement were taken on the basis of truss net work system (Fig. 1) in which eighteen landmarks, forty factor or variables plus total length of each shrimp (tip of rostrum to end of telson), totally forty one variables. From the five sample of each species the average value was taken. The significant correlations were observed between average morphometric measurement and size of the species. 
Hence for removing the effect of size variation for all species, the transformation of absolute measurement to size independent variable were carried out, in which the formula $M_{a d j}=M\left(L_{\mathrm{s}} / L_{\mathrm{o}}\right)^{b}$ was used [39]. Where $M_{a d j}$ the size adjusted measurement of each variable, $M$ is the original measurement of each variable, $L_{\mathrm{o}}$ the standard length of shrimp (total length from tip of rostrum to end of telson) and $L_{\mathrm{s}}$ the overall mean of measurement for all shrimp for each variable. Allometric vs. standard estimates allometric coefficients with respect to standard. The standard variable was placed in the first column and each additional column is regressed onto the first column after log-transformation, giving a slope (allometric coefficient) $b$ for that variable. The $L_{\mathrm{s}} / L_{\mathrm{o}}$ is computed in the excel sheet and detecting the $b$ parameter was carried out using paleontological statistics software (PAST) package version 1.93. From these sizes adjusted morphometric measurements for each species were subjected to UPGMA multivariate cluster analysis. Euclidean method (statistic tool that quantifies the extent to which species within clusters are similar to one another) was followed to detect the morphometrical relationship of Penaeidae studied using paleontological statistics software (PAST) package (Table 1-3-http://cytgen.com/ articles/4860017s.pdf).

DNA isolation. Total genomic DNA was isolated from muscle tissue by SDS-phenol/chloroform method described with slight modifications [40]. Briefly, shrimp muscle $(200 \mathrm{mg})$ was cut into small pieces, crushed using a sterile porcelain mortar and pestle with $1 \mathrm{~mL}$ of chilled TEN buffer $(50 \mathrm{mM}$ Tris$\mathrm{HCl}, \mathrm{pH}$ 8.0, $50 \mathrm{mM}$ EDTA and $100 \mathrm{mM} \mathrm{NaCl}$ ), and transferred to $2 \mathrm{~mL}$ Eppendorf tube. Proteinase K $8 \mu \mathrm{L}$ $(300 \mathrm{mg} / \mathrm{mL})$, sucrose $20 \mu \mathrm{L}(2 \%)$, and $20 \mu \mathrm{L}$ sodium dodecyl sulfate SDS (2\%) were added to the tube. After overnight incubation at $60^{\circ} \mathrm{C}$, the lysate was extracted once with phenol and twice with chloroform/isoamyl alcohol. DNA was precipitated with isopropanol, washed once with $70 \%$ ethyl alcohol, and suspended in TE (Tris EDTA, pH 8.0) buffer. DNA quality and quantity were determined by Agarose gel electrophoresis and Bio-photometer plus (Eppendorf, Germany).

RAPD-PCR amplification and data analysis. Eighteen primers were used for RAPD analysis. DNA amplification reactions were performed in $200 \mu \mathrm{mol} / \mathrm{L}$ each dNTP, $2 \mu \mathrm{mol} / \mathrm{L} \mathrm{MgCl}_{2}, 19$ standard Taq polymerase buffer, $0.2 \mu \mathrm{mol} / \mathrm{L}$ random primer, $40 \mathrm{ng}$ genomic DNA and $0.75 \mathrm{U}$ Taq polymerase in a final volume of $25 \mu \mathrm{L}$. PCR conditions included initial denaturation at $94^{\circ} \mathrm{C}$ for $5 \mathrm{~min}$, followed by 45 cycles of denaturation at $94^{\circ} \mathrm{C}$ for 30 seconds, annealing at $35^{\circ} \mathrm{C}$ for $1 \mathrm{~min}$, extension at $72^{\circ} \mathrm{C}$ for $2 \mathrm{~min}$ and final extension at $72^{\circ} \mathrm{C}$ for $10 \mathrm{~min}$. The amplified DNA was separated by electrophoresis through $2 \%$ agarose gel containing Ethidium bromide in $1 \times$ TBE buffer at a constant $80 \mathrm{~V}$. To maintain consistency, only the repeatable major bands ranging from 10000 to $1000 \mathrm{bp}$

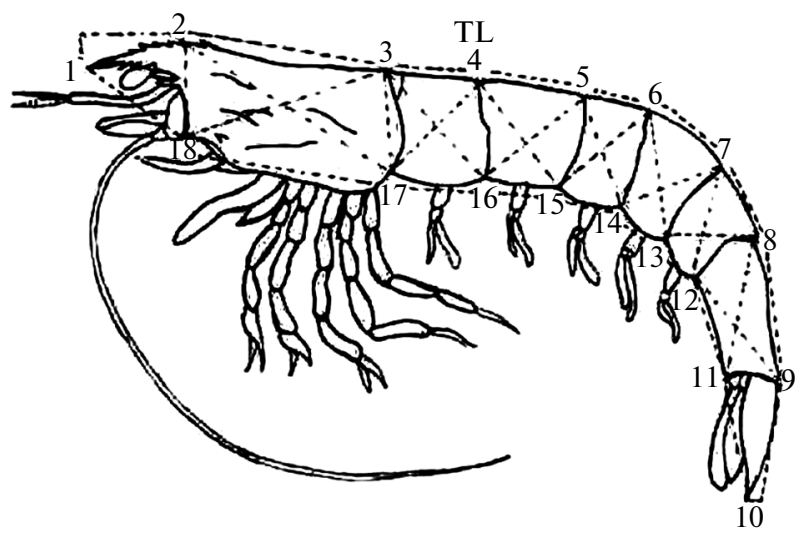

Fig. 1. The truss network system.

were scored. Molecular weights of amplified bands were estimated by comparing with known molecular weight marker (1 Kbp DNA ladder, Bangalore Genie, India). DNA profiles generated for all samples were compared in a pairwise manner. RAPD banding patterns were recorded on spread sheets as binary matrix marking alleles absent $(0)$ and present (1). The similarity index between species [41] and subsequently the data used to construct a dendrogram using the (UPGMA) algorithm, as described [42].

\section{RESULTS}

Morphometrical relationship. When converting the actual measurement value into size standaisation value, there were lot of variation between two kinds of value for most morphometical variable. The size adjusted value for all variables for all species described the relationship of species. This values were relatively closeness for Penaeus species, Metapenaeus, Parapenaeopsis and Penaeopsis jerryi. While these size adjusted morphometric value of all variables subjected to UPGMA cluster analysis, produced 10 clades. The first clade included $P$. jerryi, M. latisulcatus second, $M$. japonicas third, P. monodon-F. indicus fourth, $F$. merguiensis fifth, $P$. semisulcatus sixth, M. affinis seventh, M. brevicornis - M. dobsoni eighth, P. uncta ninth, and P. stylifera - P. hardwickii tenth (Fig. 2).

Genetic relationship. For RAPD molecular analysis, among 18 primers used, 10 primers responded, but only four primer RM03 5' AAT CGG GCT G 3', RM07 5' CAA TGC CCG T 3', RM014 5' GTA TTG CCC T 3', RM017 5' TCC CTC GTG C 3' generated good and reproducible RAPD profiles for all the species studied. Totally 99 major DNA bands produced, 11 bands polymorphic. The most number of banding pattern were similar for $F$. indicus and $P$. monodon; $P$. semisulcatus and F. merguiensis; M. latisulcatus and M. japonicas; P. stylifera, P. hardwickii and P. uncta. $P$. jerryi banding pattern vary, however most of the bands close to Metapenaeus and Parapenaeopsis spe- 


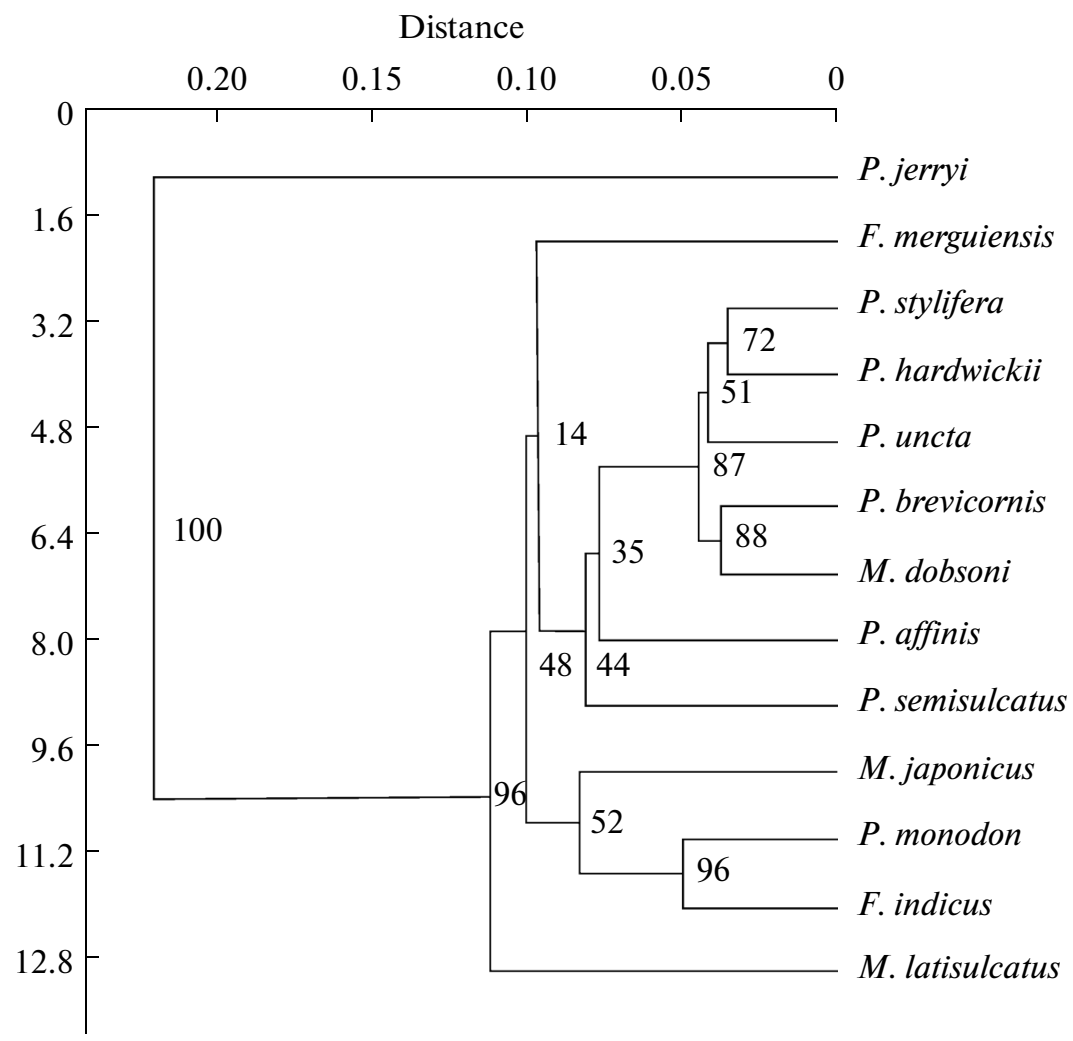

Fig. 2. Phylogeny of shrimps based on morphometric analysis using PAST Package.

cies (Fig. 3). Genetic similarity values range form $0-1$ for all isolates, and high similarity value for Penaeus genus of non-Melicertus clade species of $F$. merguiensis $P$. semisulcatus, F. indicus, $P$. monodon, than Melicertus clade species of M. japonicas and M. latisulcatus. As for Metapenaeus genus, the genetic similarity value for the species, M. affinis, M. dobsoni, M. brevicornis were closely related, and Parapenaeopsis genus the species of $P$. stylifera, $P$. hardwickii, $P$. uncta were coming closely. Penaeopsis species $P$. jerryi genetic similarity value close to Metapenaeus and the Parapenaeopsis. As construction of UPMGA dendrogram based on genetic similarity, producing 9 clades, in which the order of relationship that $M$. marsupenaeus$M$. latisulcatus in first clade, $P$. monodon-F. indicus in second, $P$. semisulcatus - $F$. merguiensis in third, $P$. jerryi, in fourth, M. affinis in fifth, M. monoceros$M$. dobsoni sixth, $P$. uncta in seventh, $P$. hardwickiiP. stylifera eighth in ninth (Fig. 4).

\section{DISCUSSIONS}

In the present study the comprehensive investigation of phylogenetic relationship of Penaeidae species by increasing number of morphometrical trait using truss net work system and many primer for RAPD analysis, resulting confirmed the phylogenetic relationship of this family. Penaeidae shrimps differ in variety of morphological characteristics that are the expression of genetic differences among them. There are, numerous studies of the morphological differences among species which can be used for taxonomic distinctions. Morphometric is a quantitative study of pattern of covariance with shape [43] and many morphological attributes of biological form are obviously reflection of evolutionary process [44-46], and since assessment of pattern of morphologically variation have been traditionally to infer phylogenetic relation [47-49] it would seem be natural to assume that morphometric analyses would play a large role in phylogenetic studies. The most of morphometrical trait are unique for a species of Penaeidae in our analysis, the closely related valued species more phylogenetic related than other. Thus the morpho-metric characters are describing the phylogenetic relationship among tested penaeidae.

Though RAPDs are not sensitive to large-scale length mutations, hence the variation might be underestimated as the technique is based on the PCR amplification of discrete regions of genome. The using of high number of primer in the present study, among which the four producing good amplification for all sample, hence the probability of reliability is high in the present study. Detecting the phylogenetic relatedness of species, on basis of DNA banding pattern the among them. Thus both morphometry and RAPD 
M Fi Pm Ps Fm Ml Mj Mb Md Ma Pas PahPau Pj M

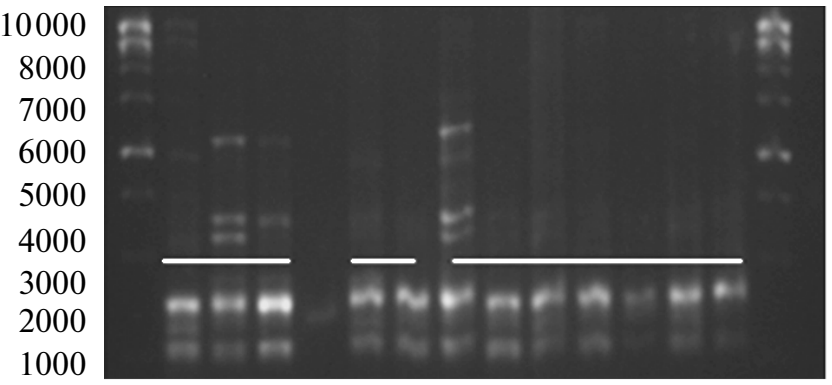

PM03
M Fi Pm Ps Fm Ml Mj Mb Md Ma PasPahPau Pj M

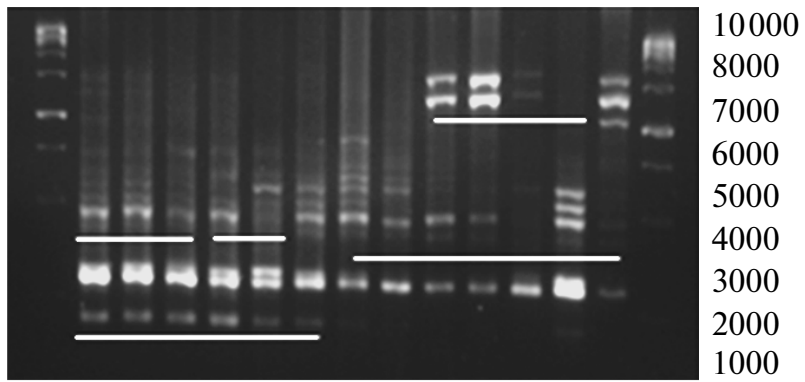

$\mathrm{Rm} 07$

M Fi Pm Ps Fm Ml Mj Mb Md Ma Pas Pah Pau Pj M

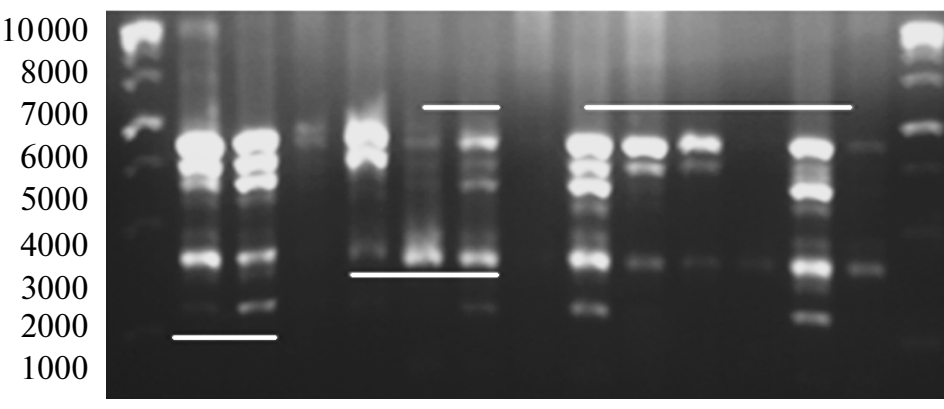

PM14
M Fi Pm Ps FmMl Mj Mb MdMaPasPahPauPj M

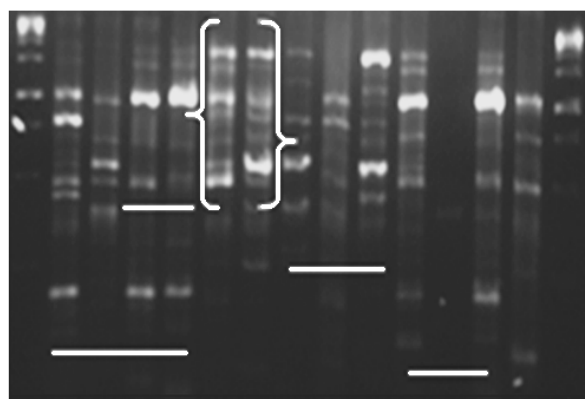

10000

8000

7000

6000

5000

4000

3000

2000

1000

$\operatorname{Rm} 17$

Fig. 3. RAPD profile of shrimps generated by polymerase chain reaction using four primer: $\mathrm{M}-\mathrm{Marker}, \mathrm{Fi}-F$. indicus, $\mathrm{Pm}-$ P. monodon, $\mathrm{Ps}-$ P. semisulcatus, Fm-F. merguiensis, $\mathrm{Ml}-$ M. latisulcatus, $\mathrm{Mj}-M$. japonicas, $\mathrm{Mb}-M$. brevicornis, $\mathrm{Md}-$ M. dobsoni, Ma-M. affinis, Pas-P. stylifera, Pah-P. hardiwickii, Pau-P. uncta, Pj-P. jerryi. Line shows the similarity of DNA bands (monomeric).

tool are helping to detect the phylogenetic relationship of Penaeidae in the present study.

The phylogenetic relationship based on morphological traits such as grooved, non grooved on the carapace, last abdominal somite, presence hepatic ridge, shape of petasma, nature of thylecum open or closed and coloration are used by [3, 4] and [37] for Penaeus s.l. not that much influence on evolutionary relationship, because these morphological characters could be diverged by sexual selection and convergent evolution, plesiomorphic, so the Penaeus s.l. group is to put old Penaeus genus, which is both morphological and molecular data agreement [32]. In the present study using both analyses, as for Penaeus sensu lato, the Melicertus and Penaeus sensu stricto (non-Melicertus) are paraphyletic which concurrent with previous phylogenetic studies [27, 28, 31, 50, 51]. The Fenneropenaeus and Penaeus s.s. are sharing their relationship, since $P$. monodon and $P$. semisulcatus combined with $F$. indicus and $F$. merguensis these observation stand on the view [22 28]. Thus Penaeus s.s., Fenneropanaeus, Farfantepenaeus and Litopenaeus could be put on another clade against Melicertus as non-Melicertus. In other Panaeidae genus such Metapenaeus and Parapenaeopsis, which are coming as closely in both analyses. This classification prevents the confusion of academic and fishery industry.
New studies should be improved than prediction of previous studies, in present study using four genera of Penaeidae family described not only evolutionary relationship but also interspecies relationship at genus

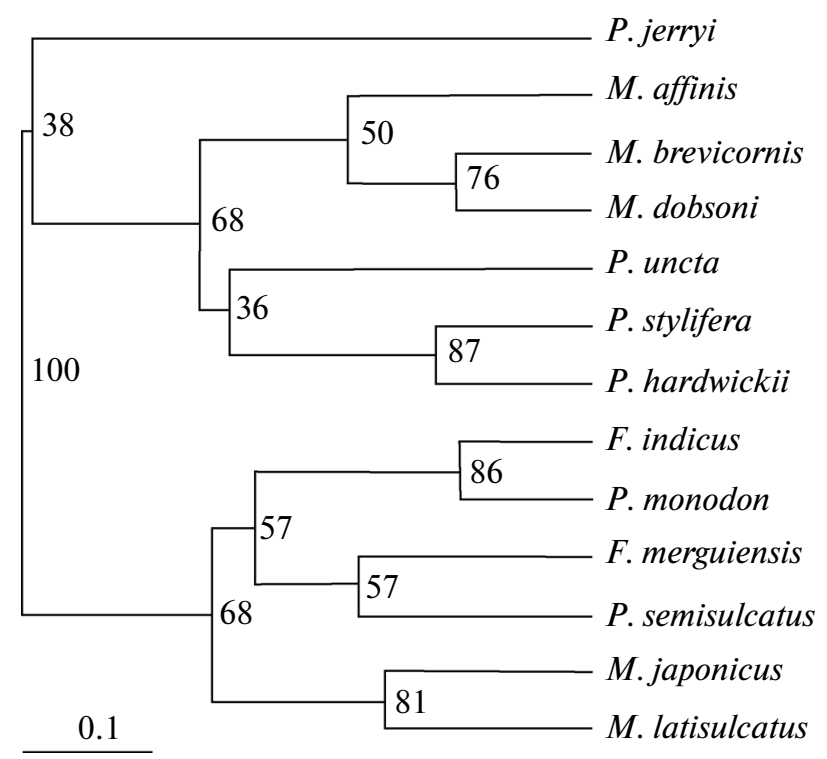

Fig. 4. Phylogenetic relatioship of Penaeidae shrimps as per RAPD analysis using UPGMA algorithm. 
level. For example as for Metapeneus species M. dobsoni and M. brevicornis are closely related than M. affinis. Parapenaeopsis species $P$. stylifera and $P$. hardwickii are closely related than $P$. uncta. The $P$. jerryi single species in Penaeopsis genus, which as one of the sister genus in the Penaeidae family as given by $[3,4]$ which form separate clade.

In the present study stand on [3] view that the tribe Peneini diverged earlier than other two tribes, with tribe Parapeneini and Trachypeneini sharing common ancestor, Penaeidae form a monophyletic group with a Penaeus shrimp as a common ancestor. Our phylognetic observations also agree with findings that evolutionary polarity of family was from Penaeus to Trachypenaeus [52]. When combined investigation of both morphometrical and genetical (RAPD) analysis of Penaeidae species, the result that both analysis outcomes are concurrent. The taxonomical relationship of genus Penaeus, in which the Melicertus and nonMelicertus clade; Metapenaeus, Parapenaeopsis and Penaeopsis are high agreement in both analyses. Phylogenetic relationship developed through this study, not only helping conservation, systematic, ecological and evolutionary studies would also help to produce superior captive shrimp with economical trait strains through hybridization of closely related species.

\section{CONCLUSION}

In the present study, phylogenetic relationship of different genera Penaeus, Metapenaeus, Parapenaeopsis, and Penaeopsis reported based on molecular tool is congruent with morphometric one. Thus it could be concluded that morphometrical traits using truss net work system more useful for phylogenic studies of Penaeidae than traditional morphological and meristematic traits. The comparative account of genetic (RAPD) and morphometric based results would be a reliable tool for confirmation of phylogenetic relationship of these economically important species. Further studies also needed to increase the numbers of Penaeidae species.

\section{ACKNOWLEDGEMENTS}

I express my sincere gratitude to Department of Science and Technology, New Delhi, India for the financial assistance provided through DST-PURSE program.

\section{REFERENCES}

1. FAO Technical Guidelines for Responsible Fisheries. Genetic Resource Management, Food and Agriculture Organization, Rome: FAO, 2008, no. 5, p. 125.

2. CMFRI Annual Report 2010-2011, Kochin, 2011, p. 163.

3. Burkenroad, M.D., Natural classification of Dendrobranchiata, with a Key to Recent Genera, in Crustacean Phylogeny, Schram, F.R., Ed., Rotterdam, 1983, pp. 279290.
4. Kubo, I., Studies on the penaeids of Japanese and its adjacent waters, J. Tokyo Coll. Fish., 1949, vol. 36, no. 1, p. 467.

5. Perez-Farfante, I., Western Atlantic shrimps of the genus Penaeus, Fish. Bull., 1969, vol. 67, no. 3, pp. 461-590.

6. Dall, W., Hill, B.J., and Rothlisberg, P.C., Biology of the Penaeidae, in Advances in Marine Biology, Sharples, D.J., Ed., London: Academic, 1990, vol. 27.

7. Strauss, R.E. and Bookstein, F.L., The truss: body form reconstruction in morphometrics, Syst. Zool., 1982 , vol. 31, no. 1, pp. 113-135.

8. Lester, L.J. and Pante, M.J.R., Genetic of Penaeus species, in Marine Shrimp Culture: Principles and Practices, Fast, A.W. and Lester, L.J., Eds., Amsterdam: Elsevier, 1992, pp. 29-52.

9. Lin, Y.S., Tzeng, C.S., and Hwang, J.K., Reassessment of morphological characteristic in freshwater eels (genus Anguilla, Anguillidae) shows, congruence with molecular phylogeny estimates, Zool. Scripta, 2005, vol. 4, no. 3, pp. 225-234.

10. Kapiris, K., Morphometric structure and allometry profiles of the giant red shrimp Aristaeomorpha foliacea (Risso, 1827) in the Eastern Mediterranean, Nat. Hist., 2005, vol. 39, no. 17, pp. 1347-1357.

11. Turan, C., Phylogenetic relationship of Mediterranean Mullidae species (Performes) inferred from genetic and morphologic data, Sci. Mar., 2006, vol. 70, no. 2, pp. 311-318.

12. Fitzerald, D.G., Nanson, J.W., Todd, T.N., and Davis, B.M., Application of truss analysis for quantification of changes in fish condition, Aquat. Ecosyst. Stress Recov., 2002, vol. 9, pp. 115-125.

13. Aktas, M., Cemal, T., and Bozkurt, A., Taxonomic description of three shrimp species (Melicertus kerathurus, Meatapenaeus monoceros, Penaeus semisulcatus) using multivariate morphometric analyses, Anim. Vet. $A d v ., 2006$, vol. 5, no. 3, pp. 172-175.

14. Brown, B. and Epifanio, J., Nuclear DNA, in Population Genetics: Principle and Application for Fisheries Scientists, Hallerman, E.M., Ed., Bethesda, 2003, pp. 101-123.

15. Avise, J.C., Molecular Markers, Natural History and Evolution, New York: Chapman and Hall, 1994.

16. Hillis, D.M., Moritz, C., and Mable, B.K., Application of molecular systematics and the future of the field, in Molecular Systematics, USA, 1996, pp. 514-543.

17. Dall, W., Recent molecular research on Penaeus sensu lato, Crustacean Biol., 2006, vol. 27, pp. 380-382.

18. Knowlton, N., Sibling species in the seas, Annu. Rev. Ecol. Syst., 1993, vol. 24, pp. 189-216.

19. Sarver, S.K., Silberman, J.D., and Walsh, P.J., Mitochondrial DNA sequence evidence supporting the recognition of two subspecies or species of the Florida spiny lobster Panilurus argus, Crustacean Biol., 1998, vol. 18, no. 1, pp. 177-186.

20. Macpherson, E. and Machordom, A., Phylogenetic relationships of species of Raymunida (Decapoda: Galatheidae) based on morphology and mitochondrial cytochrome oxidase sequences, with the recognition of four new species, Crustacean Biol., 2001, vol. 21, no. 3, pp. 696-714. 
21. Vaseeharan, B., Rajakamaran, P., Jayaseelan, D., and Yeshvadha, V.A., Molecular markers and their application in genetic diversity of penaeid shrimp, Aquacult. Int., 2013, vol. 21, pp. 219-241.

22. Chan, T.Y., Tong, J., Tam, Y.K., and Chu, K.H., Phylogenetic relationships among the genera of the Penaeidae (Crustacea: Decapoda) revealed by mitochondrial 16S rRNA gene sequences, Zootaxa, 2008, vol. 1694, pp. 38-50.

23. Voloch, C.M., Friere, P.R., and Russo, C.A., Molecular phylogeny of penaeid shrimps inferred from two mitochondrial markers, Genet. Mol. Biol., 2005, vol. 4, no. 4, pp. 668-674.

24. Quan, J., Zhuang, Z., Deng, J., et al., Phylogenetic relationship of 12 Penaeoidae shrimp species deduced from mitochondrial DNA sequences, Biochem. Genet., 2004, vol. 42, nos. 9/10, pp. 331-345.

25. Vazquez-Bader, A.R., Carrero, J.C., Gárcia-Varela, M., et al., Molecular phylogeny of superfamily Penaeoidea Rafinesque-Schmaltz, 1815, based on mitochondrial 16S partial sequence analysis, Shellfish Res., 2004, vol. 23, no. 3, pp. 911-917.

26. Ma, K.Y., Chan, T.Y., and Chu, K.H., Phylogeny of penaeoid shrimps (Decapoda: Penaeoidea) inferred from nuclear protein-coding genes, Mol. Phylogenet. Evol., 2009, vol. 53, no. 1, pp. 45-55.

27. Lavery, S., Tam, Y.K., and Chu, K.H., Phylogenetic relationship and evolutionary history of the shrimp Penaeus sp. L. derived from mitochondrial DNA, Mol. Phylogenet. Evol., 2004, vol. 31, no. 1, pp. 39-49.

28. Ma, K.Y., Chan, T.Y., and Chu, K.H., Refuting the sixgenus classification of Penaeus s.l. (Dendrobranchiata, Penaeidae); a combined analysis of mitochondrial and nuclear genes, Zool. Scripta, 2011, vol. 40, no. 5, pp. 498-508.

29. Baldwin, J.D., Bass, A.L., Bowen, B.W., and Clark, W.H., Molecular phylogeny and biogeography of the marine shrimp Penaeus, Mol. Phylogenet. Evol., 1998, vol. 10, no. 3, pp. 399-407.

30. Gusmão, S., Lazoski, C., and Solê-Cava, A.M., A new species of Penaeus revealed by allozyme and cytochrome oxidase subunit i analysis, Mar. Biol., 2000, vol. 137 , no. 3 , pp. 435-446.

31. Wang, Z.Y., Tsoi, K.H., and Chu, K.H., Applications of AFLP technology in genetic and phylogenetic analysis of penaeid shrimp, Biochem. Syst. Ecol., 2004, vol. 32, pp. 399-440.

32. Benson McRae, L.K., Morphometric and genetic confirmation of two species of Kuhlia (Osteichthyes: Kuhliidae) in Hawaii, in Biology of Hawaiian Streams and Estuaries, Evenhuis, N.L., Ed., Bishop Museum Bull. Cultur. Environ., 2007, vol. 3, pp. 113-123.

33. Dhinakaran, A., Alikunhi, N.M., Chinnathambi, S., et al., Assessment of morphometric and genetic variation in three freshwater fish species of the genus Garra (Osteichthyes: Cyprinidae), Notes. Sci. Biol., 2011, vol. 3, no. 1, pp. 12-26.

34. Young, S., Ni, M.H., and Min, Y.L., Systematic study of the Simocephalus sensu stricto species group (Cladocera: Daphniidae) from Taiwan by morphometric and molecular analyses, Zool. Stud., 2012, vol. 51, no. 2 , pp. $222-231$.
35. Choudhury, S. and Dutta, K., Study on the morphometric variation in selected ichthyofauna under genus Puntius Hamilton-Buchanan (Teleostei: Cyprinidae), J. Pharm. Biol. Sci., 2013, vol. 5, no. 3, pp. 1-6.

36. Holthuis, L.B., Shrimps and prawns of the world. An annotated catalogue of species of interest to fisheries, FAO Species Catalogue, Roma, 1980, vol. 125, no. 1.

37. Perez Farfante, I. and Kensley, B., Penaeoid and sergestoid shrimps and prawns of the world, keys and diagnoses for the families and genera, in Memoires $d u$ Museum national d'Histoire Naturelle, Paris, 1997, vol. 175, pp. 1-233.

38. Chan, T.Y., in The Living Marine Resources of the Western Central Pacific, Carpenter, K.E. and Niem, V.H., Eds., Rome: FAO, 1998, pp. 851-897.

39. Elliott, N.G., Haskard, K., and Koslow, J.A., Morphometric analysis of orange roughe (Hoplostethus atlanticus) off the continental slope of Southern Australia, J. Fish. Biol., 1995, vol. 46, no. 2, pp. 202-220.

40. Williams, J.G.K., Kubelik, A.R., Livak, K.J., et al., DNA polymorphisms amplified by arbitrary primers are useful as genetic markers, Nucleic Acids Res., 1990, vol. 18, no. 22, pp. 6531-6535.

41. Jaccard, P., Nouvelles recherches sur la distribution florale, Bull. Soc. Vaud. Sci. Nat., 1908, vol. 44, pp. 223270.

42. Rohlf, F.J., Numeral Taxonomy and Multivariate Analysis System, NTSYS-pc. Version 1.80, New York: Exeter Softeware, 1993.

43. Bookstein, F.L., Morphometric Tools for Landmark Data: Geometry and Biology, Cambridge: Univ. Press, 1991.

44. Darwin, C., On the Origin of Species by Means of Natural Selection, or the Preservation of Favored, Races in the Struggle for Life, London: John Murray, 1859.

45. Simpson, G.G., Tempo and Mode in Evolution, New York: Columbia Univ. Press, 1994.

46. Mayr, E., Animal Species and Evolution, Cambridge: Univ. Press, 1963.

47. Hennig, W., Phylogenetic Systematic, Urbana: Univ. Press, 1966.

48. Eldredge, N. and Cracraft, J., Phylogenetic Patterns and the Evolutionary Process. Method and Theory in Comparative Biology, New York: Columbia Univ. Press, 1980.

49. Mayr, E. and Ashlock, P.D., Principle of Systematic Zoology, New York: McGraw-Hill, 1991.

50. Mulley, J.C. and Latter, B.D.H., Genetic variation and evolutionary relationships within a group of thirteen species of penaeid prawns, Evolution, 1980, vol. 34, no. 5, pp. 904-916.

51. Tam, Y.K. and Chu, K.H., Electrophoretic study on the phylogenetic relationships of some species of Penaeus and Metapenaeus (Decapoda: Penaeidae) from the South China Sea, Crustacean Biol., 1993, vol. 13, no. 4, pp. 697-705.

52. Bayrami, M. and Shakunthala, V., Molecular systematic of some shrimps based on allozyme data, Res. Fish. Hydrobiol., 2010, vol. 5, no. 2, pp. 152-158. 